\title{
PENDIDIKAN KELUARGA DALAM MENINGKATKAN PENGAMALAN SHALAT ANAK
}

Oleh:

\section{Hamidah}

\begin{abstract}
The responsibility of parents for children is as carers, protectors and as educators. In the family parents are responsible for providing prayer education to children. There are a number of things parents can do in increasing the practice of child prayer when at home, that is, giving good example, having time to gather with family, motivating children to diligently study and worship, controlling physical and psychological development activities, not discouraging children want to stand alone, not embarrass children in front of people, not too discriminating and favoritism towards children in the family, and not indulging children, but not good if not caring about them.
\end{abstract}

Keywords: prayer; education; children.

\section{PENDAHULUAN}

Pendidikan merupakan proses pengubahan sikap dan tata laku seseorang atau kelompok orang dalam usaha mendewasakan manusia melalui upaya pengajaran dan pelatihan. Manusia ketika dilahirkan di dunia dalam keadaan lemah, tanpa pertolongan orang lain terutama orangtua, ia tidak bisa berbuat banyak. Dibalik keadaan yang lemah memiliki potensi yang baik yang bersifat fisik dan rohaniah. Keluarga merupakan wadah pendidikan yang sangat besar pengaruhnya dalam pembentukan akidah anak. Oleh karena itu pendidikan anak tidak dapat dipisahkan dari keluarga. Setiap orangtua tentu menginginkan anaknya menjadi orang yang berkembang secara sempurna, menginginkan anak yang dilahirkan itu kelak menjadi orang yang sehat, kuat, berketerampilan, cerdas, pandai dan beriman. Pada umumnya pendidikan dalam keluarga itu bukan berpangkal tolak pada kesadaran dan pengertian yang lahir dari pengetahuan mendidik, melainkan secara kodrati suasana dan strukturnya memberikan kemungkinan alami membangun situasi pendidikan. Situasi pendidikan itu terwujud bekal adanya pergaulan dan hubungan pengaruh mempengaruhi secara timbal balik antara orangtua dan anak.

Dalam pendidikan keluarga peran kedua orangtua merupakan aspek terpenting, karena keluarga merupakan lembaga pendidikan informal bagi pembentuakan karakter anak, dimana dalam lingkungan keluargalah berbagai macam nilai dan norma yang akan menjadi acuan atau pengangan hidup bagi anak pertama kali diperkenalkan. Menanamkan ketauhidan kepada anak sejak kecil merupakan program utama setiap orang tua yang mengidamkan kehidupan Islami. Perhatian orangtua kepada anak adalah bentuk kasih sayang yang dilakukan orangtua terhadap anaknya, karena mencintai anak adalah fitrah orangtua. Salah satu wujud kasih sayang itu adalah dengan memberikan 
pendidikan agama yang layak bagi anak-anaknya. Orangtua adalah pendidik sejati dan pendidik karena kodratnya, sehingga kasih sayang orangtua terhadap anak-anaknya merupakan kasih sayang yang sejati pula.

Rasulullah adalah teladan terbaik dalam kecintaan dan ketegasan terhadap anakanak, kasih sayang, lemah lembut, penuh perhatian beliau tampakkan kepada anakanaknya. Begitu pula kasih sayang tersebut beliau nampakkan kepada anak-anak kaum muslimin. Kendati demikian, kasih sayang Rasulullah kepada anak-anaknya tidak menghilangkan ketegasan beliau dengan cara beliau tak segan mengingatkan, bahkan marah saat melihat buah hatinya melanggar aturan Allah Swt. Semua itu beliau lakukan dalam rangka tarbiyah. Tentunya orang tua harus lebih dapat memahami bagaimana cara yang baik dalam membimbing anak yang sesuai dengan perkembangan usia, karakter dan kematangan berfikirnya sehingga arahan dan bimbingan yang diberikan orangtua kepada anak dapat di terima dan diamalkan oleh anak sebaik mungkin. Penanaman nilai ketauhidan kepada anak tidak akan sempurna apabila hanya sekedar teori semata. Untuk itu perlu adanya praktik ibadah kepada Allah Swt berupa pengamalan Shalat.

Tanggung jawab orangtua terhadap keluarga terutama terhadap anak adalah suatu hal yang sudah menjadi kewajiban, yakni sebagai pemelihara, pelindung dan sebagai pendidik. Dalam lingkungan keluarga tentu ayah dan ibunyalah yang bertanggung jawab untuk memberikan pendidikan shalat pada anak. Jika orang tua bersedia mengajarkan anak mereka tata cara shalat yang baik dan benar serta menanamkan nilai-nilai spritual shalat kedalam diri anak, hal ini akan bermanfaat untuk membangun kualitas spritual serta sosial anak, sehingga kepekaannya terhadap kebenaran akan semakin kuat begitu pula dengan kualitas shalatnya akan semakin baik. Orangtua yang bijaksana akan dapat memperlakukan anak-anaknya dengan cara yang baik, oleh karena itu orangtua harus bisa sabar dan telaten dalam mengajari setiap gerakan shalat dan senantiasa berdoa untuk kesuksesan spritual anak, khususnya dalam meningkatkan ketakwaan kepada Allah Swt. Untuk itu orangtua harus paham dan sadar bahwasanya praktik ibadah, khususnya shalat menjadi sangat penting dan merupakan langkah utama untuk menciptakan keluarga dengan penuh nuansa Islami.

\section{PERAN ORANGTUA DALAM KELUARGA}

Bagi ummat Islam, agama merupakan dasar utama dalam mendidik anak melalui sarana-sarana pendidikan. Kewajiban mendidik anak dalam keluarga dapat dilaksanakan dengan mudah dan wajar, karena orangtua mencintai anaknya. Orangtua merupakan pendidik utama dan pertama bagi anaknya, karena dari merekalah anak mula-mula menerima pendidikan. Dikatakan pendidik pertama, karena ditempat inilah anak mendapatkan pendidikan untuk pertama kali sebelum ia mendapatkan pendidikan lainnya. Kemudian dikatakan pendidik utama karena mempunyai pengaruh yang dalam bagi kehidupan anak kelak dikemudian hari. Dengan demikian peran orangtua adalah hal yang sangat penting dalam sebuah keluarga, orangtua menjadi pangkal ketentraman dan kedamaian hidup, bahkan dalam perspektif Islam keluarga bukan hanya sebagai persekutuan hidup terkecil saja, melainkan sampai pada lingkungan yang paling besar dalam arti masyarkat secara luas. Peran orangtua dalam membimbing dan mendidik anak tidak sebatas hanya sebagai orangtua saja, disisi lain orangtua harus berperan 
sebagai guru yang dapat mendidik anak dengan baik dan sesekali harus berperan sebagai polisi yang selalu siap menegakkan keadilan dan kebenaran.

Sebagai seorang guru, orangtua dituntut memiliki wawasan dan pengetahuan yang luas. Seorang ayah, disamping memiliki kewajiban untuk mencari nafkah bagi keluarganya, dia juga berkewajiban untuk mencari tambahan ilmu bagi dirinya. Melihat tinggi dan mulianya ilmu sudah selayaknya setiap orangtua membekali diri dan keluarganya dengan ilmu, mengenalkan keluarganya akan tanggung jawab yang harus ditunaikan kepada Allah Swt. Seorang ayah berkewajiban mengajari anaknya tentang thaharah dan shalat saat usianya menginjak tujuh tahun, wajib mendidik anak untuk menunaikan ibadah shalat saat usia sepuluh tahun. Kemudian mengenalkan rukun iman dan rukun islam, mengajarkan mencintai Allah Swt, Rasul dan orang-orang mukmin. Mengajarkan tentang adab-adab Islam, melatih ringan beribadah, menanamkan ketegasan dalam membenci orang yang membenci Allah Swt dan Rasulnya. Membiasakan dengan doa-doa harian, serta meluruskan berbagai pemahaman salah yang didapat dari sekolah, lingkungan dan teman-teman sebayanya. Dengan ilmu-ilmu itu dia akan dapat membimbing dan mendidik diri sendiri dan keluarganya. Demikian halnya dengan seorang ibu, disamping memiliki kewajiban dan pemeliharaan keluarga dia pun tetap memiliki kewajiban untuk mencari ilmu karena ibulah yang selalu dekat dengan anak-anaknya.

Sebagai guru orangtua juga harus telaten atas apa yang dilihat, dirasa, dan didengar oleh anak. Disamping itu orang tua juga perlu menjadi suriteladan yang baik, sebab anak mudah mentransfer ucapan dan tindakan orangtua bahkan prilaku orangtua sangat berpengaruh terhadap anak. Dalam hal ini, orangtua secara rutin mengajarkan Islam kepada anak-anaknya, misalnya setelah magrib dengan membaca Alquran dan menjelaskan secara sederhana kandungan di dalamnya dan menyediakan bacaan-bacaan yang mampu menambah keimanan dan ketaqwaan kepada Allah Swt. Sebagai polisi dalam keluarga, orangtua harus menegakkan kaedilan dan kebenaran, siapapun yang bersalah harus dihukum tanpa pandang bulu. Namun perlu diperhatikan, hukuman yang diberikan adalah hukuman yang bersifat mendidik dan positif bagi anak. Dalam memberikan hukuman pada anak, jangan sewaktu orangtua sedang emosional. Dalam hal ini orangtua juga harus melihat dan memperhatikan serta memilihkan teman yang baik, bacaan-bacaan yang baik dan lingkungan yang baik untuk mendukung kekokohan iman anak-anaknya.

Dalam pendidikan keluarga tanggung jawab juga perlu disadarkan dan dibina oleh kedua orangtua kepada anak. Tanggung jawab tersebut anatara lain :

1. Memelihara anak dan membesarkannya. Ini adalah bentuk yang paling sederhana dari tanggung jawab setiap orangtua dan merupakan dorongan alami untuk mempertahankan kelangsungan hidup manusia.

2. Melindungi dan menjamin kesehatan anak, baik secara jasmaniah maupun rohaniah dari berbagai gangguan penyakit dan bahaya lingkungan yang dapat membahayakan dirinya.

3. Mendidik anak dengan berbagai ilmu pengetahuan sehingga anak memperoleh peluang untuk memiliki keterampilan dan kecakapan seluas dan setinggi mungkin yang berguna bagi hidupnya.

4. Membahagiakan anak untuk dunia dan akhirat dengan memberikan pengajaran agama sesuai dengan ketentuan Allah Swt sebagai tujuan akhir hidup muslim. 
Orangtua juga mempunyai beban dalam mendidik yang amat berat untuk membina akhlak dan sopan santun anak, tanggung jawab itu bersifat komprehensif yang dibebankan Islam kepada seluruh ummat manusia dengan tidak meninggalkan satu orangpun dari mereka. Dengan tuntutan tersebut, Islam menjadikan orangtua bertanggung jawab penuh pada pembentukan diri yang shaleh dan tegak diatas akhlakul karimah. Orangtua mempunyi pengaruh terhadap anak sesuai dengan pinsip eksplorasi yang mereka miliki. Kataatan pada ajaran agama merupakan kebiasaan yang dimiliki anak yang mereka pelajari dari para orangtua. Oleh karena itu keluarga merupakan tempat persemaian, pembentukan atau penanaman kebiasaan. Sedangkan yang menjadi peranan penting orangtua sebagai kunci pendorong anak melakukan ajaran agama, terutama dalam masalah ibadah sholat.

Menurut pendapat lain, ada beberapa hal yang perlu ditanamkan dan disampaikan orang tua terhadap anak melalui pendidikan keluarga, yaitu :

1. Pentingnya beribadah. Orangtua harus mengajarkan kepada anak bagaimana cara beribadah agar anak menjadi anak yang saleh dan salehah.

2. Nilai jujur. Orangtua harus menyampaikan harapannya agar anak tersebut bersikap jujur melalui pemberian nasehat yang diberikan oleh orangtuanya.

3. Nilai hormat. Orangtua harus menanamkan pada anak agar terbiasa menghormati orang lain terutama kepada orang yang lebih tua. Hal ini dapat dilihat dari kepatuhan si anak kepada orangtuanya.

4. Nilai rukun. Orangtua berupaya menumbuhkan rasa atau sikap kerukunan terhadap anaknya dengan cara membiasakan untuk berbagi, bersedia mengalah, tolong menolong dan menjauhi perselisihan dalam bersaudara.

5. Nilai pencapaian prestasi. Orangtua harus membimbing anak untuk mencapai prestasi yang baik di lingkungan formal. Sebaiknya orangtua harus memberi teguran kepada anak jika prilaku dan prestasinya buruk.

Dari penjelasan diatas dapat disimpulkan bahwa tugas dan tanggung jawab orangtua adalah harus mengajarkan pendidikan aqidah, mengajarkan pendidikan akhlak untuk berbuat baik kepada orangtua dan tidak sombong ( angkuh), mengajarkan pendidkan ibadah yaitu shalat dan mengajarkan pendidikan sosial yaitu amal ma'ruf nahi munkar. Dengan demkian maka suasana hubungan orangtua dengan anak akan menjadi landasan sikap anak terhadap orangtua lain dalam kehidupan mereka secara umum.

\section{PENGAMALAN SHALAT ANAK}

Amal berasal dari bahasa Arab yang artinya berbuat. Jadi pengamalan adalah perbuatan atau penggunaan segala daya untuk menghasilkan sesuatu. Dalam hal ibadah pengamalan diartikan sebagai proses perbuatan, cara mengamalkan atau melaksanakan sesuatu untuk mencapai tujuan dan maksud yang baik. Selanjutnya pengertian shalat menurut bahasa adalah doa, sedangkan menurut istilah adalah suatu ibadah dalam bentuk perkataan dan perbuatan tertentu yang dimulai dengan takbir dan diakhiri dengan salam.

Konsep keagamaan pada diri anak dipengaruhi oleh faktor dari luar diri anak. Ketaatan pada ajaran agama merupakan kebiasaan yang dimiliki anak yang mereka 
pelajari dari orangtua maupun guru. Berdasarkan hal tersebut maka bentuk dan sifat agama pada anak dapat di bagi atas :

\section{Unreflectif (tidak mendalam)}

Sifat ini ditunjukkan anak dengan menerima kebenaran ajaran agama tanpa kritik, tidak begitu mendalam dan sekedarnya saja. Mereka sudah cukup puas dengan keterangan-keterangan walau tidak masuk akal.

\section{Egosentris}

Sifat ini ditunjukkan anak dengan prilaku melaksanakan agama anak lebih menonjolkan kepentingan dirinya dan anak lebih menuntut konsep keagamaan yang mereka pandang dari kesenangan pribadinya. Misalnya ketika anak berdoa/shalat, maka shalat yang di lakukan untuk mencapai keinginan-keinginan pribadi.

\section{Anthromorphis}

Sifat ini ditunjukkan anak dengan pemahaman anak terhadap konsep Tuhan tampak seperti menggambarkan aspek-aspek kemanusiaan. Anak memahami keadaan tuhan sama dengan manusia, bagi anak-anak tuhan dapat melihat perbuatan manusia langsung kerumah-rumah mereka seperti layaknya orang mengintai.

\section{Verbalis}

Sifat ini ditunjukkan anak dengan kegemaran menghafal secara verbal kalimatkalimat keagamaan, mengerjakan amaliah yang mereka laksanakan berdasarkan pengalaman menurut tuntutan yang diajarkan.

\section{Imitatif}

Sifat ini ditunjukkan anak dengan cara anak suka meniru tindakan keagamaan yang dilakukan oleh orang-orang di lingkungannya terutama orangtuanya.

\section{Rasa takjub/kagum}

Sifat ini ditunjukkan anak dengan berprilaku anak mengagumi keindahankeindahan lahiriyah pada ciptaan tuhan, namun rasa kagum ini belum kritis dan kreatif.

Pembagian sifat yang telah di jelaskan di atas dapat disimpulkan bahwa arangtua akan lebih mudah mengetahui apa yang harus dilakukan dalam perkembangan keberagamaan anaknya dan orangtua lebih mudah mengetahui potensi apa yang harus dikembangkan anaknya.

Shalat merupakan ibadah pokok kedua dalam rukun Islam setelah syahadatain yang wajib dan harus dilaksanakan. Allah Swt memerintahkan ummat Islam untuk melaksanakan shalat, karena shalat itu sendiri dapat mencegah perbuatan keji dan munkar. Sebagaimana firman Allah Swt dalam QS. Al-Ankabut: 45

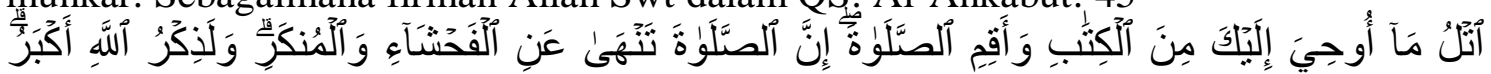


Bacalah apa yang telah diwahyukan kepadamu, Yaitu Al kitab (Al Quran) dan dirikanlah shalat. Sesungguhnya shalat itu mencegah dari (perbuatanperbuatan) keji dan mungkar. dan Sesungguhnya mengingat Allah (shalat) adalah lebih besar (keutamaannya dari ibadat-ibadat yang lain). dan Allah mengetahui apa yang kamu kerjakan.

Kewajiban untuk melaksanakan shalat fardu diturunkan Allah Swt pada malam Isra' dan Mi'raj, dan shalat sendiri sering disebut sebagai Mi'rajnya orang beriman yang mengerjakan ibadah itu. Bukan karena shalat diperintahkan saat Nabi SAW. Mengalami mukjizat itu, tetapi karena sifat ibadah ini yang menuntut komunikasi langsung antara hamba dengan Tuhannya. Pelaksanaan shalat bukan hanya gerakan jasmani saja, tetapi jasmani rohani dan akal haruslah sejalan dan terpadu ketika melaksanakan shalat. Shalat yang demikian inilah yang dapat mencegah perbuatan keji dan munkar. Kewajiban shalat tidak hanya bagi orangtua saja, tetapi orangtua juga harus mampu menanamkan pada diri anak bahwa shalat itu adalah kewajiban bagi setiap muslim. Oleh karena itu harus ditanamkan sejak dini, agar setelah dewasa kelak anak sudah terbiasa untuk shalat.

Perintah shalat bagi anak-anak bisa dijadikan sebagai suatu pembiasaan sehingga ketika anak sudah dewasa ia tidak merasa terbebani untuk melaksanakan shalat dan menjadikannya suatu kebutuhan karena sudah dibiasakan sejak kecil. Masa kanak-kanak bukan masa pembebanan atau menanggung kewajiban, tetapi merupakan masa persiapan, latihan dan pembiasaan. Karena itu anak- anak harus dilatih dan dibiasakan melaksanakan ibadah sebagai bekal mereka ketika memasuki usia baligh, dimana pada masa ini mereka sudah mendapatkan kewajiban dalam beribadah. Sehingga pelaksanaaan ibadah yang diwajiban oleh Allah Swt bukan menjadi beban yang memberatkan bagi kehidupan mereka sehari-hari, bahkan setiap jenis ibadah apapun dinilai sangat mudah pelaksanaaannya dan mempunyai kenikmatan tersendiri.

Adapun yang diperhatikan dalam melaksanakan shalat meliputi syarat sah shalat, rukun shalat dan hal-hal yang membatalkan shalat. Shalat dianggap sah menurut syara' apabila dilakukan dengan memenuhi persyaratan tertentu, yaitu : 1 . Suci dari hadats besar dan hadats kecil. 2. Suci badan, pakaian dan tempat dari najis.3. Menutup aurat. Aurat ditutup dengan sesuatu yang dapat menghalangi terlihatnya warna kulit. Adapun aurat laki-laki adalah antara pusat sampai lutut, sedangkan aurat perempuan adalah seluruh badan kecuali muka dan kedua telapak tangan.4. Mengetahui masuknya waktu shalat. 5. Menghadap kiblat ( Ka'bah ).

Kemudian yang harus diperhatikan dalam pelaksanaan shalat adalah rukunnya. Rukun shalat adalah setiap bagian shalat yang apabila salah satunya ditinggalkan dengan sengaja maka shalatnya tidak sah. Adapun rukun shalat yaitu ; 1. Niat, 2. Takbiratul ihram, 3. Berdiri bagi yang mampu (bagi orang yang tidak mampu maka boleh duduk atau berbaring), 4. Membaca surat al-Fatihah, 5. Ruku' dengan tuma'ninah, 6. I'tidal dengan tuma'ninah, 7. Sujud dua kali dengan tuma'ninahnya, 8. Duduk diantara dua sujud dengan tuma'ninah, 9. Membaca tasyahud awal, 10. Duduk pada tasyahud akhir, 11. Membaca shalawat kepada nabi pada tasyahud akhir. 12. Salam, 13. Tertib, berurutan dalam mengerjakan rukun-rukun tersebut. 
Selanjutnya yang harus diperhatikan dalam pelaksanaan shalat adalah hal-hal yang membatalkan shalat yaitu ; 1. Berbicara sekurang-kurangnya dua huruf, 2. Makan dan minum dengan sengaja, 3. Bergerak banyak dengan sengaja yang bukan gerakan dalam rukun shalat, 4. Membelakangi kiblat tanpa ada halangan, 5. Terbuka aurat, 6. Datang hadas besar atau kecil, 7. Kena najis yang tidak di maafkan pada badan, pakaian dan tempat, 8. Tertawa terbahak-bahak, 9. Murtad, gila atau pingsan, 10. Berubah niat untuk membatalkan shalat atau keluar dari shalat.

\section{UPAYA ORANGTUA DALAM MENINGKATKAN PENGAMALAN SHALAT ANAK}

Anak shaleh menjadi dambaan setiap orangtua dan merupakan investasi yang tidak pernah habis di saat investasi-investasi lain hanya bersifat sementara. Anak shaleh merupakan anak-anak yang taat kepada Allah Swt, membahagiakan kedua orangtua dan menyejukkan hati yang akan meringankan dosa-dosa kedua orangtuanya melalui doadoa yang ia lantunkan. Doa anak yang shaleh inilah yang akan menjadikan kedua orangtuanya mendapatkan kemudahan diakhirat kelak. Untuk mewujudkan itu salah satu kewajiban orangtua adalah mengajarkan anak-anak tentang shalat, karena shalat adalah pondasi seorang mukmin untuk interaksi langsung dengan Allah Swt. Jika anak diajarkan berinteraksi dengan Allah Swt sejak dini, kelak ia akan tumbuh dalam bimbingan dan naungan Allah Swt. Mengajari dan membiasakan anak shalat bukan pekerjaan mudah, karena itu Rasulullah memerintahkan untuk mengajarinya sejak usia tujuh tahun. Hal ini sebagai mana sabda beliau :

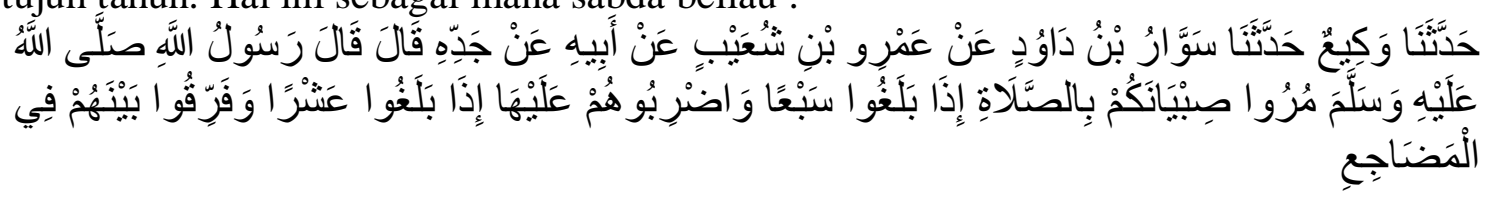

Telah menceritakan kepada kami Waqi' telah menceritakan kepada kami Sawwar bin Dawud dari 'Amru bin Syu'aib dari bapaknya dari kakeknya, dia berkata; Rasulullah Shallallahu 'alaihi wa Salam bersabda: "Suruhlah anakanak kecil kalian untuk melaksanakan shalat pada sa'at mereka berumur tujuh tahun, dan pukullah mereka (karena meninggalkannya) pada saat berumur sepuluh tahun, serta pisahkanlah tempat tidur mereka." (Hadis Riwayat Ahmad, No- 6402)

Pembinaan shalat dilakukan secara bertahap mulai dari perintah melaksanakan shalat, cara berwudhu dengan benar, bacaannya maupun gerakan-gerakan shalat. Begitu saat usia sepuluh tahun, anak sudah terbiasa shalat dengan benar, jika tidak orangtua berkewajiban terus mengingatkan. Sampai-sampai Rasulullah mengijinkan orangtua menghukum anak jika usianya mencapai sepuluh tahun bila menyepelekan shalat, tentu dengan hukuman yang tidak menyakitkan dan membuat anak trauma. Dalam hal pembinaan ini anak mulai dikenalkan pada apa itu shalat, kenapa harus shalat dan rukun serta syarat- syarat dalam melaksanakan shalat, serta larangan- larangan dalam melaksanakan shalat, kemudian membiasakan anak untuk shalat berjamaah baik dirumah maupun di mesjid. Minat anak terhadap agama sangat dipengaruhi oleh kondisi jiwa anak- anak yang suka meniru, menjelajah, ingin tahu, ingin mencoba dan 
sejenisnya. Demikian halnya dengan ibadah shalat, pada awalnya anak- anak mungkin acuh tak acuh mendengar kata shalat, namun lama kelamaan jika ia sering melihat dan diperintahkan oleh orangtuanya untuk shalat maka ia akan mencontoh orangtua untuk shalat. Orangtua yang bijak akan memperlakukan anaknya dengan cara yang baik.

Proses internalisasi pendidikan agama termasuk dalam hal ibadah shalat menjadi sangat penting bagi anak untuk dapat mengamalkan dan mentaati ajaran dan nilai-nilai agama dalam kehidupannya, sehingga tujuan pendidikan Islam tercapai. Ada beberapa hal yang dapat dilakukan orangtua dalam meningkatkan pengamalan shalat anak ketika dirumah, yaitu :

1. Memberikan keteladanan yang baik. Anak-anak belajar dengan cara melihat dan mendengar, maka orangtua harus bisa memberi teladan yang baik dalam prilaku dan perktaannya.

2. Mempunyai waktu untuk berkumpul bersama keluarga. Sesibuk apapun orangtua hendaknya dapat menyisihkan waktunya untuk berkumpul bersama keluarga untuk saling berbagi, mencurahkan rasa rindu, bercanda bersama dan sebagainya. Pada kesempatan ini akan sangat bermanfaat bagi orangtua untuk bisa menyimak bacaan sholat anak dan memperbaiki kekurangannya dan membimbingnya sehingga anak semakin paham dalam mengamalkan shalatnya.

3. Memotivasi anak untuk rajin belajar dan beribadah. Dalam memberi motivasi kepada anak dapat dilakukan dengan cara memberi pengertian, penghargaan ataupun hukuman. Hal ini sangat membantu anak untuk terus meningkatkan pengamalan shalatnya.

4. Mengontrol kegiatan dan memperhatikan perkembangan fisik dan psikis anak. Orangtua harus bisa mengontrol kegiatan anak-anaknya agar terarah dan bermanfaat bagi anak. Demikianpula dengan dengan perkembangan fisik dan psikisnya. Seiring bertambahnya usia anak, maka kematangan beragamanya juga akan turut naik, untuk itu orangtua harus mampu memberi pemahaman pada anak bahwa shalat itu bukan sekedar ritual, tetapi ia harus bisa merasakan manfaat dan pentingnya shalat. Dengan demikian anak tidak lagi merasabahwa shalat yang ia lakukan selama ini hanya sebatas melakukan kewajiban, tetapi sebaliknya ia sudah harus merasa bahwa shalat adalah suatu kebutuhan yang terus di amalkannya.

5. Jangan melemahkan semangat dalam usahnya hendak berdiri sendiri. Sebaiknya orangtua harus mendukung anak untuk menjadi mandiri dan percaya diri.

6. Jangan mempermalukan atau mengejek anak-anak di depan orang banyak.

7. Jangan terlalu membeda-bedakan dan pilih kasih terhadap anak-anak dalam keluarga.

8. Jangan memanjakan anak, tetapi tidak baik pula jika tidak memperdulikannya.

Mengacu pada sifat-sifat agama anak dan upaya membimbing kematangan beragama pada anak seyogianya dilakukan secara terpadu di lingkungan keluarga, institusi pendidikan (sekolah) dan lingkungan masyarakat. Nashih Ulwan mengemukakan beberapa upaya yang dapat dilakukan orangtua dalam meningkatkan pengamalan shalat anak dalam keluarga, yaitu :

1. Keteladanan 
Secara psikologis manusia memerlukan tokoh teladan dalam hidupnya. Meniru adalah sifat bawaan manusia, termasuk bagi anak- anak. Pendidikan dengan keteladanan dilakukan dengan memberi contoh, baik berupa tingkahlaku, sifat,cara berfikir dan sebagainya. Hal ini dikarenakan dalam belajar, anak pada umumnya lebih menangkap yang konkrit ketimbang yang abstrak. Dengan demikian orangtua bisa menggunakan metode keteladanan untuk meningkatkan pengamalan shalat anaknya dengan cara mengerjakan shalat yang benar sesuai dengan rukun syaratnya.

\section{Pembiasaan}

Pembiasaan merupakan salah satu metode pendidikan yang sangat penting terutama bagi anak-anak. Seseorang yang telah mempunyai kebiasaan tertentu akan dapat melaksanakannya dengan mudah dan senang hati bahkan segala sesuatu yang telah menjadi kebiasaan dalam usia muda sulit untuk diubah dan tetap berlangsung sampai hari tua. Sebagai orangtua menanamkan kebiasaan baik memang tidak mudah dan membutuhkan waktu yang lama. Oleh karena itu dalam mengaplikasikan pendekatan pembiasaan dalam pengamalan shalat lima waktu anak, yang harus dilakukan orangtua adalah pertama mulailah pembiasaan itu sebelum terlambat, kedua pembiasaan hendaknya dilakukan secara kontiniu, teratur, sistimatis sehingga pada akhirnya akan terbentuk sebuah kebiasaan yang utuh, permanen dan konsisten, ketiga pembiasaan yang mulanya hanya bersifat mekanisme, hendaknya secara berangsurangsur dirubah menjadi kebiasaan yang di sertai dangan kata hati anak itu sendiri.

\section{Hukuman dan Ganjaran}

Hukuman adalah tindakan yang paling akhir diambil apabila teguran dan peringatan sebelum mampu untuk mencengah anak melakukan pelanggaranpelanggaran. Sedangkan ganjaran adalah pemberian hadiah terhadap hasil-hasil yang dicapai oleh anak karena tindakan anak yang positif.

Pemberian hukuman di lakukan terhadap anak yang berprilaku buruk dengan tujuan agar ia tidak mengulanginya lagi dan agar anak menyadari kesalahan yang dilakukannya. Contohnya ketika anak meninggalkan shalat ketika sudah berusia sepuluh tahun maka anak boleh dipukul, teta pi pukulan yang mendidik. Sedangkan ganjaran dimaksudkan untuk anak yang berprilaku baik dan mendengarkan nasehat dan perintah orangtuanya. Dengan ganjaran yang diberikan kepada anak dapat memotivasi dan meningkatkan perbuatan baiknya.

Penggunaan metode hadiah dan hukuman ini hendaknya disertai dengan penggunaan metode nasehat. Nasehat tersebut dapat diberikan kepada anak yang berprilaku baik agar ia tetap istiqomah melakukan kebaikan dan kepada anak yang berprilaku buruk supaya anak tidak mengulangi kesalahannya dan menjadi lebih baik lagi.

\section{Nasehat}

Metode nasehat adalah metode yang menerapkan nasehat secara lisan maupun melalui perumpamaan, cerita dan sindiran. Dengan metode ini orangtua dapat meningkatkan pengamalan shalat anak dengan berbagai cara, seperti menceritakan keuntungan bagi orang yang menjaga shalatnya dan kerugian bagi orang yangmeningglkannya. Dalam hal ini orangtua hendaknya menasehati anak-anaknya 
dalam meningkatkan shalat. Meskipun terkadang anak mengabaikan nasehat yang di sampaikan oleh orangtuanya, namun orangtua harus tetap berusaha dan ikhlas dalam menjalankan tugasnya.

Nasehat tidak mungkin akan terwujud kecuali dengan kesungguhan orangtua untuk mendidik, mengarahkan, mendampingi dan memberikan contoh kepada anakanaknya. Inilah kewajiban besar orangtua untuk mewujudkan anak-anaknya yang shalih, sehingga anak shalih bukan sekedar bayangan, khayalan, cita-cita namun kenyataan. Dengan metode ini kita sebagai orangtua jangan pernah bosan untuk memberi nasehat kepada anak, karena lama kelamaan anak akan melaksanakannya apa yang disampaikan kepadanya dan sadar bahwa nasehat yang diberikan orangtua adalah benar untuk memperbaiki kehidupannya. Sama halnya dengan yang terdapat dalam firman Allah Swt. dalam Q.S. Luqman:17 yang menunjukkan bagaimana cara luqman menasehati anaknya yaitu dengan cara yang baik dan lemah lembut.

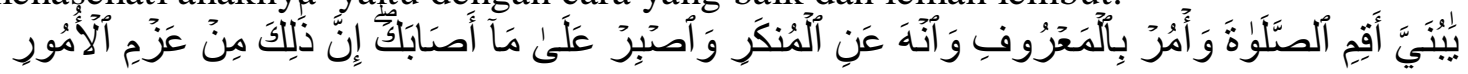

Hai anakku, dirikanlah shalat dan suruhlah (manusia) mengerjakan yang baik dan cegahlah (mereka) dari perbuatan yang mungkar dan bersabarlah terhadap apa yang menimpa kamu. Sesungguhnya yang demikian itu Termasuk hal-hal yang diwajibkan (oleh Allah).

Menjadi orangtua ideal dalam rumah tangga, tentu menjadi dambaan setiap manusia yang beriman kepada Allah Swt dan hari akhir, dan tentu saja ini tidak mudah kecuali bagi orang-orang yang dimudahkan oleh Allah Swt. Untuk itu ikhtiar dan doa terus harus dilakukan. Betapa indahnya jika orangtua penuh dengan kasih sayang terutama dengan menyertakan doa terhadap anak-anaknya agar dimudahkan untuk menunaikan kewajiban melaksanakan ibadah shalat.

\section{PENUTUP}

Dari pemaparan di atas dapat ditarik beberapa kesimpulan bahwa : Pertama, tanggung jawab orangtua terhadap keluarga terutama terhadap anak adalah suatu hal yang sudah menjadi kewajiban, yakni sebagai pemelihara, pelindung dan sebagai pendidik. Dalam lingkungan keluarga tentu ayah dan ibunyalah yang bertanggung jawab untuk memberikan pendidikan shalat pada anak. Kedua, Konsep keagamaan pada diri anak dipengaruhi oleh faktor dari luar diri anak. Ketaatan pada ajaran agama merupakan kebiasaan yang dimiliki anak yang mereka pelajari dari orangtua maupun guru. Berdasarkan hal tersebut maka bentuk dan sifat agama pada anak dapat di bagi atas : a. Unreflectif (tidak mendalam), b. Egosentris (memandang dari kesenangan sendiri), c. Anthromorphis (Tuhan dapat melihat perbuatan manusia langsung kerumahrumah mereka seperti layaknya orang mengintai. d. Verbalis (mengerjakan amaliah yang mereka laksanakan berdasarkan pengalaman menurut tuntutan yang diajarkan), e. Imitatif (anak suka meniru tindakan keagamaan yang dilakukan oleh orang-orang di lingkungannya terutama orangtuanya), f. Rasa takjub/kagum (Anak mengagumi keindahan-keindahan lahiriyah pada ciptaan tuhan, namun rasa kagum ini belum kritis dan kreatif).

Ada beberapa hal yang dapat dilakukan orangtua dalam meningkatkan pengamalan shalat anak ketika dirumah, yaitu: a. Memberikan keteladanan yang baik. 
b. Mempunyai waktu untuk berkumpul bersama keluarga. c. Memotivasi anak untuk rajin belajar dan beribadah. d. Mengontrol kegiatan dan memperhatikan perkembangan fisik dan psikis anak. e. Jangan melemahkan semangat dalam usahnya hendak berdiri sendiri. f. Jangan mempermalukan atau mengejek anak-anak di depan orang banyak. g. Jangan terlalu membeda-bedakan dan pilih kasih terhadap anak-anak dalam keluarga. $\mathrm{h}$. Jangan memanjakan anak, tetapi tidak baik pula jika tidak memperdulikannya.

Beberapa upaya yang dapat dilakukan orangtua dalam meningkatkan pengamalan shalat anak dalam keluarga, yaitu: a. Keteladanan, b. Pembiasaan, c. Nasehat, d. Hukuman dan Ganjaran.

\section{DAFTAR PUSTAKA}

Aly, Hery Noer. Ilmu Pendidikan Islam, Jakarta: Logos, 1999.

Akhdhiyat, Beni Ahmad Saebani dan Hendra. Ilmu Pendidikan Islam, Bandung: Pustaka Setia, 2009.

Fatimah, Muhammad Zairul Haq dan Sekar Dina. Cara Jitu Mendidik Anak agar saleh dan shaleha, Jakarta: Elex Media Komputindo, 2015.

al-Hasyimi, Muhammad Ali. Jati Diri Wanita Muslimah, Jakarta: Pustaka al-Kausar, 1997.

Hafsah. Fiqih, Bandung: Citapustaka Media Perintis, 2011.

Lestari, Sri. Psikologi Keluarga: Penanaman Nilai dan Penanganan Konflik dalam Keluarga, Jakarta: Kencana, 2012.

Munir, Samsul. Menyiapkan Masa Depan Anak Secara Islami, Jakarta: Amzah, 2007.

Mulia, Ahmad Thib Raya dan Siti Musdah. Menyelami Seluk Beluk Ibadah dalam Islam, Bogor: Kencana, 2003.

Masganti. Psikologi Agama, Medan: Perdana Publishing, 2011.

Purwanto, M. Ngalim. Ilmu Pendidikan Teoritis dan Praktis, Bandung: Rajawali, 2010.

Syafaruddin. Ilmu Pendidikan Islam, Jakarta: Hijri Pustaka Umum, 2006.

Syahraini. Pendidikan Komunikasi Islam: Pemberdayaan Keluarga Membentuk Kepribadian Anak, Jakarta: Kalam Mulia, 2013.

Tafsir, Ahmad. Ilmu Pendidikan Islam, Bandung: Remaja Rosdakarya, 2016. 